\title{
TIPE KESALAHAN MAHASISWA DALAM MENYELESAIKAN SOAL-SOAL GEOMETRI BERDASAR NEWMAN'S ERROR ANALYSIS (NEA)
}

\author{
Anita Dewi Utami \\ IKIP PGRI Bojonegoro \\ e-mail: anitadewiutami55@gmail.com
}

\begin{abstract}
The students' ability to solve mathematical problems are affected directly or indirectly by their pattern of problem solving when they were attending primary and secondary schools. The result of observation shows that there are students who can not answer proving problem and take no action at all, thoughit is only at the step of understanding the problem. NEA is a frame work with simple diagnostic procedures, which include (1) decoding, (2) comprehension, (3) transformation, (4) process skills, and (5) encoding. Newman's developed diagnostic method is used to identify the error categories of descriptive test answer. Therefore, the descriptive types of students' error in proving problem solving in Geometry 1 subject based on Newman's error Analysis (NEA), and what are the causes for the student's mistakes in solving those proving problem, especially in Geometryl subject is interesting to be discussed in this article.
\end{abstract}

Key Words: Problems of Geometry, Type of student's mistakes, Newman's error Analysis (NEA)

\begin{abstract}
Abstrak: Kemampuan mahasiswa dalam menyelesaikan soal-soal matematika secara langsung ataupun tidak langsung dipengaruhi oleh pola penyelesaian soal pada saat mahasiswa duduk di bangku sekolah dasar maupun menengah. Hasil pengamatan peneliti menujukkan bahwa masih terdapat mahasiswa yang tidak bisa menjawab soal pembuktian dan tidak melakukan tindakan apapun, meskipun hanya pada tahapanunderstand the problem. NEA merupakan kerangka kerja dengan prosedur diagnostik sederhana, yang meliputi (1) decoding, (2) comprehension, (3)transformation, (4) processskill, dan (5) encoding. Metode diagnostik yang dikembangkan Newman ini digunakan untuk mengidentifikasi kategori kesalahan terhadap jawaban dari sebuah tes uraian. Sehingga bagaimana deskripsi jenis kesalahan mahasiswa dalam menyelesaikan soal-soal pembuktian pada mata kuliah Geometri 1 berdasarkan Newman's Error Analysis(NEA), dan apa saja penyebab kesalahan mahasiswa dalam menyelesaikan soalsoal pembuktian, khususnya pada mata kuliah Geometri 1, menarik untuk dibahas dalam tulisan ini.
\end{abstract}

Kata Kunci: Soal-soal Geometri, Tipe Kesalahan Mahasiswa, dan Newman's Error Analysis (NEA)

\section{PENDAHULUAN}

Kemampuan mahasiswa dalam menyelesaikan soal-soal matematika dipengaruhi oleh pola penyelesaian soal pada saat mahasiswa duduk di bangku sekolah dasar maupun menengah. Kebiasaan menjawab soal pilihan ganda pada saat ujian nasional telah berpengaruh terhadap kemampuan mahasiswa menyelesaikan soal-soal uraian di perguruan tinggi terutama soal-soal pembuktian.

Hasil riset internasional mengenai kinerja siswa di Indonesia dalam menyelesaikan soal pemecahan masalah masih belum memuaskan. Beberapa hasil penelitian Trends International Mathematics and Science Study (TIMSS), Programme for International Student Assessment (PISA), 
The Political and Economic Risck Consultancy (PERC) dan lainnya menunjukkan bahwa kemampuan peserta didik di Indonesia terhadap matematika masih pada kategori rendah. Sebagai contoh hasil studi dari PERC menunjukkan bahwa pendidikan di Indonesia jika dibandingkan dengan dengan Vietnam, ternyata Indonesia masih di bawah Vietnam (Hayat, 2008).

Pada umumnya guru dan siswa masih menggunakan strategi jawab singkat dalam menyelesaikan soal. Guru tidak perlu mengetahui proses kesalahan yang dibuat siswa dalam menjawab soal, karena penilaian konvesional (paper andpencil test) tidak dapat menganalisis kesalahan jawab (Enger dan Yager, 2001). Selain itu Thompson (2008) juga menyatakan bahwa guru masih mengalami kesulitan dalam menafsirkan kemampuan berpikir versi taksonomi Bloom. Hal ini dikarenakan kebanyakan guru hanya mementingkan hasil akhir, bukannya proses siswa dalam menjawab soal. Siswa yang tidak terbiasa menjawab soal melalui serangkaian alur berpikir matematis berdampak pada pendidikan lanjut di perguruan tinggi. Pada saat mahasiswa diberi soal uraian terutama pembuktian, mahasiswa mengalami ke'asulitan dalam menuangkan ide-idenya dalam bahasa penulisan. Mahasiswa kesulitan membuat reasoning dan prosedur penyelesaian secara benar dan logis. Hal ini mengakibatkan hasil kerja mahasiswa dalam menjawab soal tidak dapat dipahami dosen.

Kinerja mahasiswa dalam menyelesaikan soal matematis perlu dianalisis sehingga kesalahan mahasiswa dapat diketahui. Salah satu alat yang dapat digunakan adalah analisis kesalahan dengan prosedur NEA (Newman's Error Analysis). Menurut Newman (1983), NEA merupakan kerangka kerja dengan prosedur diagnostik sederhana, yang meliputi (1) decoding, (2) com- prehension, (3) transformation, (4) process skill, dan (5) encoding. Metode diagnostik yang dikembangkan Newman ini digunakan untuk mengidentifikasi kategori kesalahan terhadap jawaban dari sebuah tes uraian.

Tahap decoding, yakni kesalahan yang terjadi karena mahasiswa tidak dapat mengenali atau membaca istilah dalam soal, tidak mengenali simbol atau tidak mengetahui apa yang ditanyakan soal, atau mahasiswa tidak dapat membaca pertanyaan secara lengkap. Untuk tahap comprehension, kesalahan yang dianalisis adalah mahasiswa tidak memahami istilah, frase atau tidak mengetahui pertanyaan secara komprehensif. Pada tahap transformation, kesalahan yang dianalisis adalah pada saat mahasiswa tidak mampu mengubah informasi dalam pertanyaan ke simbol matematika, operasi dan kalimat matematika dengan benar, dalam istilah Polya dikenal dengan tidak dapat melakukan device a plan for solving it. Tahap process skill, yakni analisis kesalahan mahasiswa terhadap ketidakmampuan mahasiswa dalam menerapkan langkah-langkah perhitungan dengan benar ketika menerapkan prosedur atau algoritma meskipun telah berhasil menulis kalimat matematika sesuai dengan pertanyaan yang diminta. Tahap akhir dari prosedur NEA adalah encoding, yakni ketika mahasiswa tidak dapat menulis jawaban yang benar atau tepat dalam bentuk angka, simbol atau kata-kata meskipun telah melalui tahapan 'process skill', mahasiswa dalam menyelesaikan soal ini didasarkan pada ranah tujuan pembelajaran sesuai dengan taxonomiBloom yang telah direvisi, untuk ranah analyze, evaluate, dan create (Anderson dan Krathwohl, 2001). Ketiga ranah tersebut termasuk dalam kategori Highr Order Thinking (HOT). Kemampuan HOT merupakan proses mental yang memungkinkan mahasiswa dapat mengembangkan pengetahuan fak- 
tual, pengetahuan prosedural, pengetahuan konseptual, dan pengetahuan metakognitif dalam domain kritis dan kreatif (McMahon, 2007). Karena itu diperlukan analisis terhadap kinerja mahasiswa dalam menyelesaikan soal-soal pembuktian. Dengan dilakukan analisis terhadap kinerja mahasiswa tersebut, diharapkan diketahui kesalahankesalahan yang dilakukan mahasiswa sehingga ke depan dapat dilakukan perbaikan.

Berdasarkan uraian pada latar belakang, pertanyaan penelitian ini adalah: (1) bagaimana deskripsi jenis kesalahan mahasiswa dalam menyelesaikan soal-soal pembuktian pada mata kuliah Geometri 1 berdasar Newman's ErrorAnalysis (NEA), dan (2) apa saja penyebab kesalahan mahasiswa dalam menyelesaikan soal-soal pembuktian pada mata kuliah Geometri 1? Tujuan penelitian ini adalah (1) untuk memperoleh deskripsi jenis kesalahan mahasiswa dalam menyelesaikan soal-soal pembuktian pada mata kuliah Geometri 1 berdasar Newman's Error Analysis (NEA), dan (2) untuk memperoleh penyebab kesalahan mahasiswa menyelesaikan soal-soal pembuktian pada mata kuliah Geometri 1.

Manfaat dari penelitian ini adalah ditemukan rujukan yang terkait dengan jenis dan penyebab kesalahan mahasiswa dalam menyelesaikan soal-soal pembuktian. Sehingga kedepannya dosen dapat menggunakan strategi yang tepat dalam membelajarkan mahasiswa terkait soal-soal pembuktian pada mata kuliah Geometri 1.

\section{METODE}

Jenis penelitian ini adalah penelitian kualitatif. Hal ini dikarenakan peneliti hendak mengungkap suatu fenomena yang dialami oleh subjek penelitian yang berupa perilaku, persepsi, motivasi, tindakan, dan lain-lain, secara holistik dan dengan cara deskripsi dalam bentuk kata-kata dan baha- sa, pada suatu konteks khusus yang alamiah dan dengan memanfaatkan berbagai metode ilmiah (Molleong, 2009).

Penelitian ini dilakukan di Program Studi Pendidikan Matematika IKIP PGRI Bojonegoro. Subjek penelitian adalah mahasiswa yang mengambil mata kuliah Geometri 1 pada semester Ganjil Tahun Akademik 2015/2016. Jumlah subjek sebanyak 36 mahasiswa yang mengikuti kuliah Geometri 1.

Teknik pengumpulan data menggunakan teknik (1) tes, (2) tugas-tugas terstruktur, dan (3) wawancara. Tes dan tugastugas terstruktur berupa soal-soal uraian yang telah divalidasi ahli. Wawancara difokuskan pada kesalahan yang dibuat mahasiswa pada jawaban tes maupun tugastugas. Wawancara dikelompok pada aspek reading (decoding), comprehension, transformation, process skill, dan encoding. Untuk mengukur keabsahan data digunakan triangulasi metode yaitu dengan membandingkan hasil tes dan hasil wawancara.

Data jawaban mahasiswa selanjutnya dianalisis berdasarkan Model Alir dari Miles dan Hubermen (1992). Analisis tersebut meliputi (1) reduksi data, (2) penyajian data, dan (3) penarikan kesimpulan/ verifikasi. Reduksi data yang dilakukan adalah meliputi proses pemilihan, pemusatan perhatian pada penyederhanaan, pengabstrakan, dan trasnformasi data kasar. Kegiatan reduksi ini dihasilkan klasifikasi berdasarkan tipe kesalahan menurut prosedur NEA. Selajutnya data disajikan dalam bentuk naratif dan tabel. Hasil klasifikasi, sajian data, dan simpulan merupakan konfigurasi yang utuh dan selanjutnya dicari makna hasil penelitian.

\section{HASIL DAN PEMBAHASAN}

Data hasil penelitian ini meliputi data kuantitatif dan kualitatif. Data kuanti- 
tatif adalah skor hasil tes dari tiga kali tes, dan data kualitatif adalah hasil analisis dari tiga kali tes. Tes I adalah tes formatif, Tes II adalah tes dari Mid tes, tes III adalah soal
Ujian akhir. Soal yang dianalisis pada penelitian ini adalah 1 soal pembuktian dari 3 soal yang diberikan. Data tersebut tersaji dalam Tabel 1 berikut.

Tabel 1. Persentase Hasil Tes Soal Pembuktian Per aspek Geometri 1 Semester Ganjil Tahun Ajaran 2014/2015.

\begin{tabular}{lllccc}
\hline \multirow{2}{*}{ No. } & \multirow{2}{*}{ Aspek Tahapan Polya } & \multicolumn{3}{c}{ Persentase Jawaban (\%) } \\
\cline { 3 - 5 } & & Tes 1 & Tes 2 & Tes 3 \\
\hline 1. & Understand the problem & 52,8 & 61,1 & 77,8 \\
\hline 2. & Device a plan for solving it & 47,2 & 58,3 & 77,8 \\
\hline 3. & Carry out the plan & 47,2 & 50 & 69,4 \\
\hline 4. & Solution obtained & 38,9 & 50 & 69,4 \\
\hline
\end{tabular}

Sumber: Data 36 Mahasiswa prodi pendidikan matematika tahun ajaran 2014/2015

Dari Tabel 1 diketahui bahwa dari skor pada setiap tahapan diketahui bahwa jawaban pada setiap tes meningkat untuk semua aspek tahapan. Hal ini diduga pengaruh dari pembelajaran yang dilakukan dan umpan balik pada setiap akhir tes. Pada tes pertama meskipun telah dibelajarkan tahapan penyelesaian soal menurut tahapan Polya dan strategi pemecahan soal dari Zevenbergen et al (2004), mahasiswa masih belum memiliki pengalaman dalam pemecahan soal. Sebagai contoh pada tes pertama, mahasiswa mestinya dapat memanfaatkan gambar (strategi make a drawing), tetapi masih banyak mahasiswa tidak melakukan, sehingga mahasiswa banyak gagal dalam device a plan for solving. Hal yang sama juga terjadi pada tes 2 . Untuk tes yang ketiga mahasiswa telah banyak melakukan strategi look for pattern, sehingga hanya sedikit mahasiswa yang gagal dalam melakukan device a plan for solving. Temuan yang menarik adalah terdapat 8 mahasiswa dari 33 mahasiswa yang secara permanen tidak menjawab soal pembuktian dari tes I, II sampai tes III. Hasil wawancara diperoleh bahwa mahasiswa tidak mengerjakan soal pembuktian karena merasa tidak cukup waktu untuk mengerjakan, tetapi setelah dikaji lebih mendalam ternyata mahasiswa tersebut lebih mendahulukan soal-soal algoritma biasa yang bukan pembuktian. Hasil wawancara secara mendalam diketahui ternyata pada mahasiswa yang secara permanen tidak mau menjawab soal pembuktian, dikarenakan secara psikologis mahasiswa tersebut tidak ada keinginan untuk mencoba terlebih dahulu dan merasa tidak sanggup mengerjakan terhadap soal-soal pembuktian.

Hasil penelitian menunjukkan bahwa tidak setiap mahasiswa yang dapat menyelesaikan tahapan understand the problem, dapat melakukan device a plan for solving dengan benar. Masih banyak mahaiswa yang gagal dalam menentukan device a plan for solving. Hal yang sama juga terjadi pada tahap carry out the plan, di mana tidak setiap mahasiswa yang dapat menyelesaikan dengan baik device a plan for solving, tetapi gagal dalam perhitungan atau tidak teliti. Ketidaktelitian dan kegagalan dalam perhitungan mengakibatkan hasil akhir atau solusi akhir tidak diperoleh hasil secara tepat. Ketidaktelitian dalam perhitungan ini menunjukkan bahwa mahasiswa tidak melakukan look back, reflet on the solution obtained. Berdasarkan skor yang diperoleh sebagaimana tersaji dalam Tabel 2, diperoleh kesimpulan bahwa pembimbingan dalam pembelajaran tentang bagaimana menyelesaikan soal pemecahan masalah telah berdampak pada peningkatan mahasiswa dalam menyelesaikan soal-soal pembuktian dengan baik. Strategi penyele- 
saian melalui identify unwanted information, create a table, make adrawing, look for pattern, act in out, use simpler example, guess and check, make generalisations, work backwards, dan check the answer dari Zevenbergen et al (2004), telah membantu mahasiswa dalam menyelesaikan soal pembuktian.
Setelah jawaban mahasiswa dinilai (diskor), tahap selanjutnya data jawaban mahasiswa dianalisis dengan menggunakan NEA. Pengelompokkan analisis dibagi dalam kategori (1) decoding, (2) comprehension, (3) transformation, (4) process skill, dan (5) encoding. Data hasil analisis disajikan dalam Tabel 2 berikut.

Tabel 2. Persentase Kesalahan Mahasiswa pada Tiap Periode Tes

\begin{tabular}{ccccc}
\hline \multirow{2}{*}{ No. } & \multirow{2}{*}{ Kategori } & \multicolumn{3}{c}{$\begin{array}{c}\text { Persentase Kesalahan Mahasiswa } \\
\text { Tiap Periode Tes (\%) }\end{array}$} \\
\cline { 3 - 5 } & & Tes 1 & Tes 2 & Tes 3 \\
\hline 1. & Decoding & 40 & 18,2 & 14,8 \\
\hline 2. & Comprehension & 50 & 27,3 & 18,5 \\
\hline 3. & Transformation & 65 & 31,8 & 22,2 \\
\hline 4. & Process Skill & 75 & 40,9 & 22,2 \\
\hline 5. & Encoding & 85 & 54,6 & 22,2 \\
\hline
\end{tabular}

Keterangan:

1. Jawaban salah mahasiswa tiap kategori dibagi jumlah mahasiswa yang mengerjakan.

2. Pada Tes 1 data yang dianalisis sebanyak 20 orang dari 36 mahasiswa.

3. Pada Tes 2 data yang dianalisis sebanyak 22 orang dari 36 mahasiswa.

4. Pada Tes 3 data yang dianalisis sebanyak 27 orang dari 36 mahasiswa.

Dari Tabel 2 diketahui bahwa semakin tinggi kategori semakin banyak kesalahan yang dibuat mahasiswa. Keadaan ini terjadi pada setiap periode tes. Terdapat mahasiswa yang berhasil pada kategori decoding, tetapi gagal pada kategori comprehension. Demikian juga mahasiswa yang berhasil pada kategori transformation, tetapi gagal dalam process skill. Kegagalan juga berlanjut terhadap beberapa mahasiswa yang berhasil dalam process skill, tetapi keberhasilannya tidak dilanjutkan pada kategori encoding. Kegagalan mahasiswa dalam tahap encoding disebabkan mahasiswa tidak melakukan check the answer. Hasil wawancara diketahui bahwa mahasiswa yang gagal dalam encoding dikarenakan tidak cukup waktu untuk mengecek jawaban kembali. Pada tes yang ketiga keberhasilan mahasiswa semakin baik.
Secara lebih detail, jenis kesalahan yang dilakukan mahasiswa dalam menyelesaikan soal pada setiap kategori disajikan pada Tabel 3. Pada Tabel 3 analisis dilakukan pada jawaban mahasiswa pada setiap kategori. Analisis dilakukan seperti berikut: (1) kesalahan jawaban pada tahap decoding tidak dapat dilakukan analisis pada kategori berikutnya, sehingga pada mahasiswa yang membuat kesalahan pada kategori decoding, analisis tidak dilanjutkan pada kategori comprehension, transformation, process skill, maupun encoding, (2) kesalahan jawaban yang dilakukan mahasiswa pada kategori comprehension, analisis tidak dilanjutkan pada kategori transformation, process skill, maupun encoding, demikian juga pada transformation, process skill, dan (3) pada mahasiswa yang telah menjawab sampai pada kategori encoding analisis dilakukan pada semua kategori. 
Tabel 3. Deskripsi Jenis Kesalahan Mahasiswa pada Tiap Periode Tes Geometri 1

\begin{tabular}{|c|c|c|}
\hline No. & Kategori & Deskripsi Kesalahan Mahasiswa Pada Tiap Periode Tes \\
\hline 1. & Decoding & $\begin{array}{l}\text { Jenis kesalahan mahasiswa pada kategori ini berupa: (1) tidak mengidentifikasi } \\
\text { permasalahan secara tepat, (2) menuliskan informasi-informasi yang tidak } \\
\text { diperlukan dalam soal, dan (3) dalam mengidentifikasi informasi masih ada yang } \\
\text { kurang. Hasil analisis diketahui bahwa mahasiswa belum mengetahui generalisasi } \\
\text { dari suatu bukti, sehingga mahasiswa mengambil contoh atau permisalan yang } \\
\text { dianggap sebagai bukti. }\end{array}$ \\
\hline 2. & Comprehension & $\begin{array}{l}\text { Jenis kesalahan yang terjadi pada kategori comprehension ini adalah: (1) } \\
\text { mahasiswa tidak utuh dalam mengidentifikasi hal yang ditanyakan, (2) kurang } \\
\text { tepat dalam membuat manipulasi aljabar sehingga gagal dalam proses } \\
\text { transformasi(transformation), (3) memahami pertanyaan hanya kasus per kasus. }\end{array}$ \\
\hline No. & Kategori & Deskripsi Kesalahan Mahasiswa Pada Tiap Periode Tes \\
\hline 3. & Transformation & $\begin{array}{l}\text { Jenis kesalahan mahasiswa pada kategori ini diantaranya adalah sebagai berikut: } \\
\text { (1) kesalahan dalam merencanakan solusi, (2) kesalahan menggunakan operasi } \\
\text { hitung karena pemahaman terhadap soal kurang komprehensif, (3) kesalahan } \\
\text { dalam membuat manipulasi, dan (4) tidak membuktikan tetapi membuat contoh } \\
\text { permisalan. }\end{array}$ \\
\hline 4. & Process Skill & $\begin{array}{l}\text { Jenis kesalahan mahasiswa pada kategori process skill meliputi (1) kesalahan } \\
\text { dalam menerapkan prosedur, (2) kesalahan dalam melakukan hitungan, seperti } \\
\text { operasi kurang keliru operasi tambah, (3) tidak berhati-hati dalam melakukan } \\
\text { berhitungan, (4) dan (5) kesalahan dalam melakukan manipulasi. }\end{array}$ \\
\hline 5. & Encoding & $\begin{array}{l}\text { Jenis kesalahan pada kategori encoding meliputi: (1) tidak teliti dalam membuat } \\
\text { simpulan, (2) tidak melakukan pemeriksaan terhadap perhitungan sehingga salah } \\
\text { dalam menuliskan hasil akhir, dan (3) tidak mengecek kembali apa yang } \\
\text { ditanyakan, sehingga salah dalam menuliskan hasil akhir. }\end{array}$ \\
\hline
\end{tabular}

Dari data pada Tabel 3 diketahui bahwa pada tahapan decoding terdapat mahasiswa yang tidak mengidentifikasi permasalahan secara tepat, dan menuliskan variabel-variabal atau informasi yang tidak diperlukan, informasi yang kurang dan hanya memberi contoh. Hasil wawancara secara mendalam diketahui bahwa mahasiswa tersebut hanya berspekulasi dalam menjawab, dan tidak memiliki keyakinan dapat menyelesaikan soal dengan benar. Mahasiswa hanya berharap memperoleh skor dari jawaban yang dibuat, karena merasa tidak kosong lembar jawabnya.

Kesalahan yang dibuat pada kategori comprehension salah satunya adalah mahasiswa tidak utuh dalam mengidentifikasi hal yang ditanyakan. Hasil wawancara diketahui bahwa mahasiswa tersebut tidak memahami makna yang ditanyakan, mahasiswa hanya menuliskan secara tekstual informasi yang ada di dalam soal. Mahasiswa tersebut hanya memahami pertanyaan kasus per kasus dan menganggap bahwa satu kasus cukup dapat menyelesaikan soal. Pada kasus ini mahasiswa menjawab soal pembuktian hanya dengan memberi contoh dari suatu kasus, yang hanya benar untuk satu kasus. Penyebab dari kesalahan mahasiswa ini dikarenakan mahasiswa tidak memahami generalisasi dari suatu pembuktian.

Pada mahasiswa yang jawabnya memberikan contoh, bukti dari kasus berarti mahasiswa gagal dalam melakukan transformasi, sehingga berakibat (1) kesalahan dalam merencanakan solusi, (2) kesalahan dalam menggunakan operasi hitung karena pemahaman terhadap soal kurang komprehensif, (3) kesalahan dalam membuat manipulasi. Penyebab dari kesalahan ini karena mahasiswa tergesa-gesa dalam menyelesai- 
kan soal. Untuk mahasiswa yang melakukan kesalahan pada process skill, dari wawancara mendalam diketahui bahwa mahasiswa tergesa-gesa dalam melakukan perhitungan sehingga dihasilkan jawaban yang salah maupun kesalahan dalam operasi hitung. Kesalahan dalam process skill juga diketahui karena mahasiswa kesulitan dalam melakukan manipulasi perhitungan. Namun demikian setelah dilakukan scaffolding pada saat wawancara diketahui mahasiswa mampu menyelesaikan soal dengan benar. Kegagalan pada process skill berakibat pada kegagalan memperoleh hasil akhir.

Kesalahan pada saat encoding adalah meliputi: (1) tidak teliti dalam membuat simpulan, (2) tidak melakukan pemeriksaan terhadap perhitungan sehingga salah dalam menuliskan hasil akhir, dan (3) tidak mengecek kembali apa yang ditanyakan, sehingga salah dalam menuliskan hasil akhir. Hasil wawancara diketahui bahwa mahasiswa merasa tidak cukup waktu untuk menyelesaikan soal. Hal ini dikarenakan secara umum mahasiswa dalam menyelesaikan soal-soal tes, baik soal mid semester maupun soal ujian akhir hanya mengutamakan soal-soal algoritma (soal-soal rutin).

\section{SIMPULAN}

Berdasarkan hasil penelitian jenis kesalahan mahasiswa kategori decoding diantaranya adalah (1) tidak mengidentifikasi permasalahan secara tepat, (2) informasi yang tidak diperlukan ditulis secara detail, dan (3) dalam mengidentifikasi informasi banyak yang kurang. Pada mahasiswa yang melakukan kesalahan pada kategori decoding, juga melakukan kesalahan pada kategori comprehension, transformation, process skill, dan encoding akan lebih kompleks lagi.

Sedangkan jenis kesalahan pada kategori comprehension meliputi: (1) maha- siswa tidak utuh dalam mengidentifikasi hal-hal yang ditanyakan, (2) mahasiswa tidak tepat membuat manipulasi aljabar sehingga gagal dalam proses transformasi (transformation), (3) mahasiswa hanya memahami pernyataan kasus per kasus.

Jenis kesalahan mahasiswa pada kategori transformation diantaranya: (1) mahasiswa salah dalam merencanakan solusi, (2) mahasiswa salah dalam menggunakan operasi hitung karena pemahaman terhadap soal kurang komprehensif, (3) kesalahan dalam membuat manipulasi, dan (4) mahasiswa hanya membuat contoh permisalan tetapi tidak dapat membuktikan.

Jenis kesalahan mahasiswa pada kategori process skill diantaranya adalah (1) kesalahan dalam menerapkan prosedur yang diinginkan oleh soal, (2) kesalahan dalam melakukan hitungan, seperti operasi kurang dan operasi tambah, (3) tidak berhati-hati dalam melakukan perhitungan sehingga salah dalam menentukan hasil, dan (4) kesalahan dalam melakukan manipulasi.

Jenis kesalahan pada kategori encoding meliputi: (1) mahasiswa tidak teliti dalam membuat simpulan, (2) tidak melakukan pemeriksaan terhadap perhitungan sehingga salah dalam menuliskan hasil akhir, dan (3) tidak mengecek kembali apa yang ditanyakan, sehingga salah dalam menuliskan hasil akhir.

Kesalahan yang paling panyak dilakukan mahasiswa dalam mengerjakan soal pembuktian adalah pada tahap comprehension. Kesalahan pada tahap ini mengakibatkan kegagalan pada tahap pengerjaan berikutnya. Kesalahan mahasiswa yang paling sedikit adalah tahap encoding. Secara umum kesalahan pada tahap encoding, karena kekurang telitian mahasiswa dalam menjawab dan tidak memeriksa kembali proses dan hasil jawaban. 
Kesalahan mahasiswa dalam menyelesaikan soal-soal pembuktian, antara lain disebabkan karena: (1) mahasiswa kurang memahami generalisasi dari soal pembuktian, (2) mahasiswa tergesa-gesa dalam melakukan perhitungan, (3) mahasiswa tidak teliti dalam melakukan manipulasi atau perhitungan, (4) mahasiswa tidak melakukan cek akhir dari proses jawaban. Saran dari penelitian ini adalah mahasiswa perlu DAFTAR PUSTAKA

Anderson dan Krathwohl. 2001. A Taxonomy for leraning, teaching, and Assessing. United States: Addison Wesley Longman, Inc.

Enger, S.K. dan Yager, R.E. 2001. Assessing Student Understanding in Science. California: Corwin Press, Inc.

Hayat, B. 2008. Prinsip-Prinsip dan Strategi Penilaian di kelas dalam Assessment BerbasisKelas. Jakarta: Pusat Penilaian pendidikan, Badan Penelitian dan Pengembangan Depdiknas. Thompson, T. 2008. Mathematics Teachers Interpretation of Higher Order Thinking in Blooms Taxonomy dalam IEJME, Vol. 3(2), pp. 82-102.

McMahon, G. P. 2007. Getting the HOTS with what's in the box: Developing higherorderthinking skills within a mendapat pembelajaran yang lebih banyak dalam menyelesaikan soal-soal pemecahan masalah (pembuktian atau soal dari kasus konstekstual yang tidak rutin), tes pemecahan masalah akan lebih optimal jika mahasiswa diberikan kesempatan untuk open book (buka buku) dan buka buku lebih mengurangi ketegangan mahasiswa, dan tes pemecahan masalah mengurangi kemungkinan mahasiswa untuk mencontek.

technology-rich learning environment. Thesis presented for the Degree of Doktor of Philosophy of Curtin University of Technology.

Miles, M. B dan Huberman, A. M. 1992. Analsisis data Kualitatif terjemah Rohidi, T. Jakarta: UI Press.

Moleong, L.J. 2009. Metodologi Penelitian Kualitatif. Bandung: Remaja Rosdakarya. Newman, M.A. 1983. Strategies for Diagnosis and Remediation. Sydney: Harcourt, Brace Jovanovich.

Newman, M.A. 1983. Strategies for Diagnosis and Remediation. Sydney: Harcourt, Brace Jovanovich.

Thompson, T. 2008. Mathematics Teachers Interpretation of Higher Order Thinkng in Blooms Taxonomy dalam IEJME, Vol. 3(2), pp. 82-102. 